\title{
Structure, Conduct and Performance of Tomato Retailers in Abeokuta South, Ogun State, Nigeria
}

\author{
Egbeadumah Maryanne Odufa ${ }^{1}$, Djomo Raoul Fani $^{2}$, Ewung Bethel ${ }^{2}$ \\ ${ }^{1}$ Department of Agricultural Economics and Extension, Federal University Wukari. Taraba State, \\ Nigeria \\ ${ }^{2}$ Department of Agricultural Economics. University of Agriculture, Makurdi. Benue-State, Nigeria. \\ Makurdi \\ raoulfani@gmail.com
}

\begin{abstract}
The unique characteristics of agricultural products including tomatoes pose a lot of problems both to the farmer and final consumer. Its seasonality, small unit production and bulkiness exert various pressures on handling, packaging, transportation and sales with an adverse attendant effect on the market price. The perishable nature of tomato and the loss incurred during marketing calls for attention. Hence, this study was carried out to analyze structure, conduct and performance of tomato retailers in Abeokuta South, Ogun State, Nigeria. A multistage and simple random sampling technique was used in selecting the respondents. A total of 80 tomato retailers were randomly from eight (8) markets. Data were collected using structured questionnaires and interview schedule, administered on the respondents were analyzed using descriptive statistics and graph such as: marketing margin, marketing efficiency, Gini coefficient and Lorenz curve. The study revealed that tomato retailing is a profitable business with a marketing margin (M.M) of 536 Naira. The study further revealed that tomato retailers are economically efficient with a marketing efficiency (M.E) of 1.31 and finally tomato retailing is competitive as well as there is inequality of income among tomato retailers with a Gini coefficient of 0.8 despite the fact that transportation, losses due to breakage, losses due to rodent attack, poor quality of products and shortage in supply were identified as major problems encountered by tomato retailers in the study area. It is therefore recommended that appropriate infrastructure should be constructed in the study area to ease the movement of goods to markets which will therefore minimize cost incurred by tomato retailers.
\end{abstract}

Keywords: Structure, Conduct, Performance, Tomato Retailers

\section{INTRODUCTION}

Tomato is a fruit vegetable that serves as low cost method of providing adequate supplies of vitamins, minerals and fibre to the people who live in Nigeria (Ihekeronye et al. 1985). It contributes to the nutritional balance of the diet. Suffice to say that the potential of tomato in the tropics is great. Wide spread cultivation of tomatoes is capable of generating rural employment as well as stimulate urban employment. This is possible through provision of business opportunities for manufacture of fertilizer, pesticides, sprayers and containers (tins, cans and bamboo crates, cardboard, foil, plastics or wood) (Egbeadumah, 2008). The high perishability of tomato discourages many farmers from going into large scale production; and prevents growers from increasing their scale of production. This has resulted in low productivity in processing industries and high prices of both fresh and processed tomato products (Egbeadumah, 2008). Market structure relates especially to the degree of competition in a market. It tends to consider whether the number of firms producing products is large or whether the firms are of equal sizes or dominated by small group. It is concerned with whether entry for new firms is easy or not. Structure also relate to the degree of market knowledge which is available to these firms (Vu Trong and Casabianca, 2002). Market conduct refers to possible practices of collusion or exclusion, in addition to price-fixing methods. While Market performance on the other hand, is the assessment of how well the process of marketing is carried out and how successfully its aims are accomplished (Vergriette, 2002). According to these analyses, markets of developing countries are generally characterized by imperfect competition and poor circulation of information, which calls for a better match between supply and demand through the establishment of "modern" wholesale markets and market information systems (Goosens et al. 1994; Mohtar, 2000). However, in marketing system, the structure, conduct and performance of a market is one of the most important approaches to analysis of market. This encourages the participation of a large number of individuals at various types 
of markets and exchange points where the marketing services of assembling, storage, processing, transportation and break-of-bulk are performed (Egbeadumah, 2008). As a result of the short shelf life of tomato, the huge losses incurred by growers and in order to ensure that farmers and marketing agents get a high return on their capital investment. This study is aimed among other things to critically analyze structure, conduct and performance of tomato retailers in Abeokuta South, Ogun State, Nigeria as well as problems faced by them with a view of proffering useful suggestion to reducing the problem to the minimum.

\section{METHODOLOGY}

The Study Area: The study was carried out in Abeokuta South local government area of Ogun State. Abeokuta is situated about $100 \mathrm{~km}$ north of Lagos and $70 \mathrm{~km}$ south-west of Ibadan. It is divided into two local government areas, Abeokuta north and Abeokuta south local governments which jointly accounts for $16 \%$ of the human population in Ogun State. (Foss, 1999). The forest belt has an average rainfall of about $1455 \mathrm{~mm}$ with a slightly bimodal rainfall distribution which peaks in June and October, while the dry season stretches from mid November to mid March. It has a temperature range of $27^{\circ} \mathrm{C}$ to $32^{\circ} \mathrm{C}$ and average humidity of $80 \%$ to $90 \%$.

Population, Sampling procedure and Data Collection: A sample of the population was taken by adopting multi stage and simple random sampling procedure based on the number of existing markets in Abeokuta South local Government. In the first stage eight (8) markets were selected such as: Kuto, Adatan, Omida, Ibarapa-Ake, Itoku, Ijaiye, Panseke and Ita-morin. In the second stage 10 retailers were randomly selected in each of the eight (8) markets. Having drawn the number of markets (8) in the study area, thus a total of 80 tomato retailers were randomly selected for the study. Data were collected through the administration of 80 copies of well structured questionnaires to selected respondent. Some respondent who have no formal education were interviewed to get first hand information. This is to cater for all categories of people in the marketing channel of tomato.

\section{Variable Specification/Model Specification}

Marketing Margin: This is the difference between the price the final consumer pays for the commodity and the cost of a unit of the good at the farm gate. It was used as a measure of market conduct to evaluate tomato price among retailers.

Marketing margin (MM) is computed as: $\mathrm{MM}=$ Selling price - Purchase price

Marketing Efficiency: According to Olukosi and Isitor (1990), marketing efficiency is the maximization of the ratio of output to input in marketing. Thus, marketing costs are the cost of providing marketing services such as transportation, rent, storage and association dues. Total revenue is the benefit or satisfaction created or value added to the commodity or product as it passes through the marketing system such as income of the marketers. It was used as a measure of market performance to evaluate tomato price among retailers.

Market Efficiency $=\frac{\text { Total Revenue }}{\text { Total Cost }}$

\section{Gini Coefficient}

The Lorenz curve and Gini coefficient were used together to assess the structure of the tomato market in the study area. These twin analytical procedures were used to determine the degree of market concentration among tomato retailers in the study area.

Suppose we have the cumulative relative frequencies of income and households.

\begin{tabular}{|c|c|}
\hline Cumulative relative frequency of income (Y) & Cumulative relative frequency of households (X) \\
\hline$y_{1}$ & $x_{1}$ \\
\hline$y_{2}$ & $x_{2}$ \\
\hline$y_{3}$ & $x_{3}$ \\
\hline$y_{4}$ & $x_{4}$ \\
\hline$y_{5}$ & $x_{5}$ \\
\hline$y_{6}$ & $x_{6}$ \\
\hline$y_{7}$ & $x_{7}$ \\
\hline$y_{8}$ & $x_{8}$ \\
\hline
\end{tabular}


Denoting the Gini coefficient by $G$, we have

$$
G=\frac{A}{A+B}
$$

Which must lies between 0 and 1 . When there is total equality the Lorenz curve coincides with the $45^{\circ}$ line, area $A$ then disappears and $G=0$. With total inequality (one household having all the income), area $B$ disappears and $G=1$. Alternatively, the Gini coefficient can be expressed as:

$$
G=\frac{A}{A+B}=\frac{A+B}{A+B}-\frac{B}{A+B}=1-\frac{B}{A+B}
$$

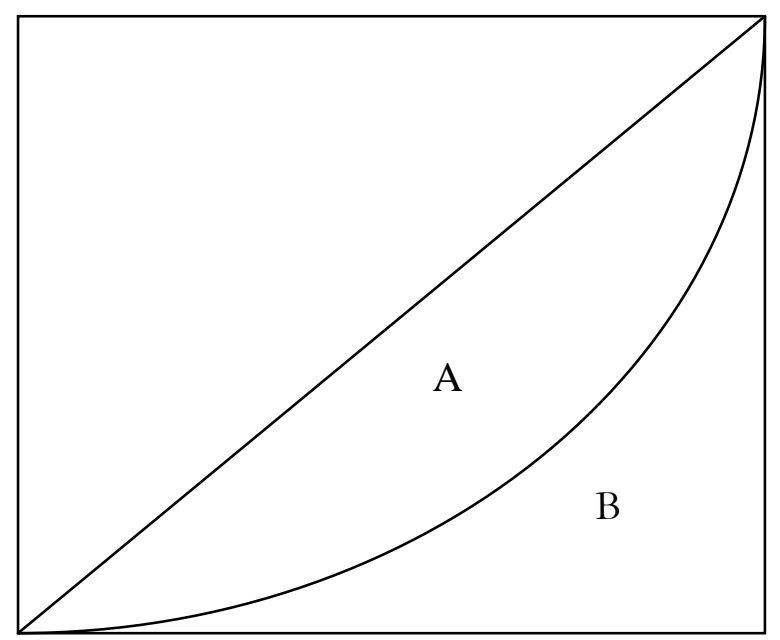

\section{RESULTS AND DISCUSSION}

\section{Socio-Economic Characteristics of Tomato Retailers in Abeokuta South, Ogun State, Nigeria}

Table 1 describes the socio-economic characteristics of tomato retailers in Abeokuta South which include sex; age; marital status; education, years spent in school; experience; household size and labour type.

Analysis of sex of tomato retailers indicated that $98.75 \%$ of respondents were female while $1.25 \%$ was male. This implies females are predominantly involved into tomato business. The mean age of respondents is 38.7 years implying that majority of tomato retailers are within the economically active age. Specifically, $16.25 \%$ of tomato retailers' age range is between 21 to 30 years; $42.5 \%$ of respondents' age range is between 31 to 40 years; $33.75 \%$ of respondent's age range is between 41 to 50 years and $7.5 \%$ of respondent's age range is between 51 to 60 years. Following Ogunyinka (1997) age is an important determinant of an individual's capability to undertake marketing activities. The older a business man or woman is, the lesser he or she can physically perform operation and the more he or she will have to depend on the use of agents or hired labour. As for marital status, $75 \%$ of the respondents are married, $10 \%$ are single, $11.3 \%$ are divorced and $3.8 \%$ are widowed/widower. Since majority of tomato retailers were married, there is a tendency that tomato retailers are more stable as marriage guarantees stability in their activities which may lead to increase their market performance from learning by constant practice. The study further revealed that $63.8 \%$ of the respondents have attended formal education, $18.8 \%$ have attended quranic education and $17.6 \%$ did not attend any form of education. As for number of years spent in school by respondents, $35.1 \%$ did not attend any form of school; $21.3 \%$ attended primary school; $12.5 \%$ attended junior secondary school; and $31.3 \%$ of attended senior secondary school. These results imply that tomato retailers are literate enough to adopt any form of strategies in order to improve their businesses. As for household size, $10 \%$ of tomato retailers have household size of 1 to 4 members; $62.5 \%$ of respondents have 5 to 8 members; $23.8 \%$ of respondents have 9 to 12 members; $2.5 \%$ of respondents have 13 to 16 members and finally $1.3 \%$ of respondents have 21 and above members. Since majority of have household have 5 to 8 members there is an evidence of the availability of family labour as well as household size is of great importance to sustain small scale business. As for labour, $90 \%$ of tomato retailers use family labour while only $10 \%$ of tomato retailers use hired labour. This implies that family members participate actively in terms of labour use to the sustainability of tomato business in the study area. 
Egbeadumah et al.

Table1: Socio-economic characteristics of Tomato Retailers in Abeokuta South, Ogun State, Nigeria

\begin{tabular}{|c|c|c|}
\hline Variables & Frequency & Percentage $(\%)$ \\
\hline \multicolumn{3}{|l|}{ Sex } \\
\hline Male & 1 & 1.25 \\
\hline Female & 79 & 98.75 \\
\hline Total & 80 & 100 \\
\hline \multicolumn{3}{|l|}{ Age range (years) } \\
\hline $21-30$ & 13 & 16.25 \\
\hline $31-40$ & 34 & 42.5 \\
\hline $41-50$ & 27 & 33.75 \\
\hline $51-60$ & 6 & 7.5 \\
\hline Total & 80 & 100 \\
\hline \multicolumn{3}{|l|}{ Marital status } \\
\hline Single & 8 & 10 \\
\hline Married & 60 & 75 \\
\hline Divorced & 9 & 11.2 \\
\hline Widowed/Widower & 3 & 3.8 \\
\hline Total & 80 & 100 \\
\hline \multicolumn{3}{|l|}{ Educational status } \\
\hline Formal & 51 & 63.8 \\
\hline Quranic & 15 & 18.8 \\
\hline None & 14 & 17.6 \\
\hline Total & 80 & 100 \\
\hline \multicolumn{3}{|l|}{ Years spent in school } \\
\hline None & 28 & 35.1 \\
\hline Primary & 17 & 21.3 \\
\hline Junior secondary school & 10 & 12.5 \\
\hline Senior secondary school & 25 & 31.3 \\
\hline Total & 80 & 100 \\
\hline \multicolumn{3}{|l|}{ Household size } \\
\hline $1-4$ & 8 & 10 \\
\hline $5-8$ & 50 & 62.5 \\
\hline $9-12$ & 19 & 23.8 \\
\hline $13-16$ & 2 & 2.5 \\
\hline $21 \&$ above & 1 & 1.3 \\
\hline Total & 80 & 100 \\
\hline \multicolumn{3}{|l|}{ Labour type } \\
\hline Hired labour & 8 & 10 \\
\hline Family labour & 72 & 90 \\
\hline Total & 80 & 100 \\
\hline
\end{tabular}

\section{Sources: Field Survey 2010}

\section{Marketing Margin (Market Conduct)}

The marketing margin is the difference between the cost price of sales of fresh tomatoes and the selling price. The cost of tomato for the retailers entails the (usually acquired per basket), cost of transportation, tables, baskets used for selling the tomato

\begin{tabular}{|c|}
\hline AFOA $=1.4$ times per week \\
\hline $\mathrm{AQBP}=9$ baskets \\
\hline $\mathrm{AQB}=1.4 * 9=13$ baskets per week \\
\hline $\mathrm{ASP}=\mathrm{N} 1,032.7$ \\
\hline $\mathrm{PP}=\mathrm{N} 12,889.00$ \\
\hline $\mathrm{SP}=\mathrm{N} 13,425.1$ \\
\hline $\mathrm{MM}=\mathrm{SP}-\mathrm{PP}=\mathrm{N} 536.1$ \\
\hline $\mathrm{TR}=\mathrm{N} 38,174.1$ \\
\hline $\mathrm{TC}=\mathrm{N} 29,135.38$ \\
\hline $\mathrm{M} . \mathrm{E}=1.31$ \\
\hline
\end{tabular}


(AFOA) Average Frequency of access of the marketers to buy tomato $=1.4$ times per week

(AQBP) Average quantity purchased $=9$

(AQB) Quantity of baskets purchased $=13$ baskets per week.

(ASP) Average selling price of basket $=\mathrm{N}, 1032.7$

$(\mathrm{SP})$ Selling price $=($ quantity $*$ price $)$

$$
\begin{aligned}
& =13 * 1032.7 \\
& =\mathrm{N} 13,425.1
\end{aligned}
$$

(PP) Purchase price $=$ N12889.00

Therefore, Market Margin (M.M) = Selling Price - Purchase Price (variable cost)

$\mathrm{M} . \mathrm{M}=\mathrm{N} 13,425.1-\mathrm{N} 12,889.00=\mathrm{N} 536.1$

The marketing margin shows that tomato retailing is a profitable enterprise

\section{Marketing Efficiency (Market Performance)}

A market is efficient when marketing efficiency equals to or is greater than one and a market is inefficient if the marketing efficiency is less than one.

The result of Market Efficiency (M.E) is 1.31 and shows that for every naira invested, 1.31 naira is realized. Therefore, tomato retailers in Abeokuta south are economically efficient.

$$
\text { Market Efficiency (M.E) }=\frac{\text { Total Revenue }}{\text { Total Cost }}
$$

Market Efficiency (M.E) $=\underline{38,174.1}=1.31$

$$
29,135.38
$$

\section{Market Structure}

Table 2 summarized the sale made by tomato retailers and was categorized with an interval of 5000 . Table 2 shows that $3.75 \%$ of the retailers who fall into a monthly sales of $0-5000$ naira control $0.43 \%$ of the market share, $5 \%$ of the retailers who are in the category of $5001-1000$ naira monthly sales control $1.5 \%$ of the market share, $5 \%$ of the retailers who are in the category of $10001-15000$ naira monthly sales control $1.69 \%$ of the market share, $13.75 \%$ of the retailers who are in the category of 15001-20000 naira monthly sales control $6.38 \%$ of the market share, $18.75 \%$ of the retailers who are in the category of $20001-25000$ naira monthly sales control $10.99 \%$ of the market share, $21.25 \%$ of the retailers who are in the category of 25001 - 30000 naira monthly sales control $15 \%$ of the market share, $6.25 \%$ of the retailers who are in the category of $30001-35000$ naira monthly sales control $5.3 \%$ of the market share, $2.5 \%$ of the retailers who are in the category of $35001-40000$ naira monthly sales control $2.5 \%$ of the market share and $23.75 \%$ of the retailers who are in the category of 40001 and above monthly sales control $56.71 \%$ of the market share.

The Gini coefficient of 0.8 shows that there is inequality in revenue realization by the tomato sellers. With a Gini coefficient value of 0.8 which is closer to 1 . This result when compare to the value $(0.74)$ obtained by Taru et al. (2010) in their study on structural analysis of paddy markets in southern part of taraba state, Nigeria indicates that the tomato market is competitive in Abeokuta South, Ogun State, Nigeria.

Table 2: Average monthly sales of tomato retailers in Abeokuta South, Ogun State, Nigeria

\begin{tabular}{|c|c|c|c|c|c|c|c|}
\hline $\begin{array}{c}\text { Category } \\
\text { of sales } \\
(\mathrm{N})\end{array}$ & $\begin{array}{c}\text { Number } \\
\text { of } \\
\text { tomato } \\
\text { sellers }\end{array}$ & $\begin{array}{c}\text { Proportion } \\
\text { of retailers } \\
(\mathrm{Y})\end{array}$ & $\begin{array}{c}\text { Cumulative } \\
\text { proportion of } \\
\text { retailers }\end{array}$ & $\begin{array}{c}\text { Total } \\
\text { value of } \\
\text { monthly } \\
\text { sales (N) }\end{array}$ & $\begin{array}{c}\text { Proportion } \\
\text { of monthly } \\
\text { sales (Z) }\end{array}$ & $\begin{array}{c}\text { Cumulative } \\
\text { proportion of } \\
\text { monthly } \\
\text { sales }\end{array}$ & Y.Z \\
\hline $1-5000$ & 3 & 0.0375 & 0.0375 & 13000 & 0.004257 & 0.00426 & 0.00016 \\
\hline $5001-$ & 4 & 0.05 & 0.0875 & 31250 & 0.010233 & 0.01449 & 0.000512 \\
\hline 10000 & 4 & 0.05 & 0.1375 & 51500 & 0.016864 & 0.03135 & 0.000843 \\
\hline $10001-$ & 4 & &
\end{tabular}


Egbeadumah et al.

\begin{tabular}{|c|c|c|c|c|c|c|c|}
\hline \hline $\begin{array}{c}15000 \\
\begin{array}{c}15001- \\
20000\end{array}\end{array}$ & 11 & 0.1375 & 0.275 & 194833.3 & 0.063798 & 0.09515 & 0.008772 \\
\hline $\begin{array}{c}20001- \\
25000\end{array}$ & 15 & 0.1875 & 0.4625 & 335666.7 & 0.109913 & 0.20506 & 0.020609 \\
\hline $\begin{array}{c}25001- \\
30000\end{array}$ & 17 & 0.2125 & 0.675 & 458250 & 0.150053 & 0.35512 & 0.031886 \\
\hline $\begin{array}{c}30001- \\
35000\end{array}$ & 5 & 0.0625 & 0.7375 & 161833.3 & 0.052992 & 0.40811 & 0.003312 \\
\hline $\begin{array}{c}35001- \\
40000\end{array}$ & 2 & 0.025 & 0.7625 & 75674.05 & 0.024779 & 0.43289 & 0.000619 \\
\hline $\begin{array}{c}40001 \& \\
\text { above }\end{array}$ & 19 & 0.2375 & 1 & 1731917 & 0.567112 & 1 & 0.134689 \\
\hline \begin{tabular}{c} 
Total \\
\hline
\end{tabular} & 80 & 1 & & 3053924 & 1 & & 0.201402 \\
\hline
\end{tabular}

\section{Sources: Field Survey 2010}

The Lorenz curve shows in figure 1 the nature of the distribution of sales among the retailers in the study area. It is the graphical representation of the Gini coefficient and market structure, it indicates the cumulative distribution of the sales against cumulative distribution of the retailers. The graph shows the deviation from the absolute equality, hence, giving a measure of the degree of inequality of the sales distribution.

Figure 1: Lorenz curve for retailers of tomato marketers in Abeokuta south

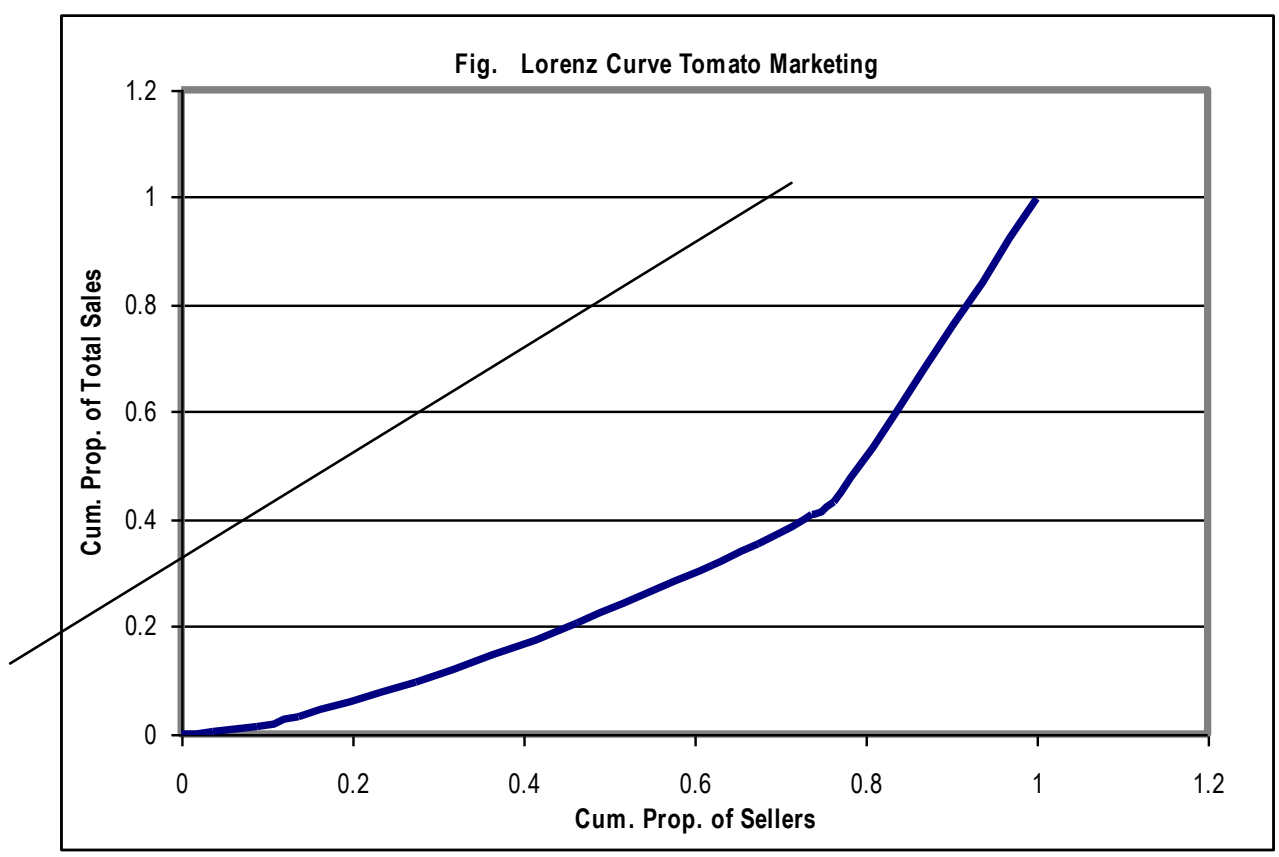

\section{Problems Commonly Encountered In Marketing of Tomato}

Table 3 shows the common problems facing tomato retailers in Abeokuta south local government. The top five problems facing the retailers are transportation, losses due to breakage, losses due to rodent attack, poor quality of products and shortage in supply.

Table 3: Problems commonly encountered by tomato marketers

\begin{tabular}{|l|l|}
\hline Problem type & Ranks \\
\hline Transportation & 1 \\
\hline Losses due to breakage & 2 \\
\hline Insect/rodent attack & 3 \\
\hline Unripe & 4 \\
\hline Inadequate quantity & 5 \\
\hline Others & 6 \\
\hline
\end{tabular}

Source: Field Survey, 2010 N.B 1 is the most common problem and 5 is the problem with the least occurrence. 


\section{CONCLUSION AND RECOMMENDATIONS}

This study was carried out to analyse structure, conduct and performance of tomato retailers in Abeokuta South, Ogun State, Nigeria. It was found that tomato retailing is a profitable business with a marketing margin (M.M) of 536 Naira. The study further revealed that tomato retailers are economically efficient with a marketing efficient (M.E) of 1.31 and finally tomato retailing is competitive as well as there is inequality of income among tomato retailers with a Gini coefficient of 0.8 despite the fact that transportation, losses due to breakage, losses due to rodent attack, poor quality of products and shortage in supply were identified as major problems encountered by tomato retailers in the study area. It is therefore recommended that:

i) Tomato retailers should be encouraged to remain in the business

ii) Appropriate infrastructure should be constructed in the study area to ease the movement of goods to markets which will therefore minimize cost incurred by tomato retailers.

iii) Membership association should also be encouraged among tomato retailers in order to minimize losses

\section{REFERENCES}

Egbeadumah, M. O. (2008). Structure Conduct and performance of Tomato Marketing in Abeokuta South, Ogun state. B.Sc. project submitted to the Department of Agricultural Economics. University of Agriculture, Abeokuta, Ogun State, Nigeria.

Foss, K. (1999). A transaction cost perspective on the influence of standards on product development: Examples from the fruit and vegetable market, Druid Working Paper $\mathrm{n}^{\circ}$ 96-9, $26 \mathrm{p}$.

Goosens, F., Minten, B., and Tollens, E. (1994). Nourrir Kinshasa. KU Leuven et L'Harmattan,Louvain et Paris, 397 p.

Ihekeronye, A.I and Ngoddy, P.O (1985): Integrated food science and technology for the tropics. Macmillian publishers. Pp. 293- 296.

Mohtar, S., 2000. The operation of wholesale markets in Malaysia. FAO series, Aliments dans les villes (http://www.fao.org/ag/agsm/sada).

Olukosi, J.O. and Isitor S.U. (1990). Introduction to Agricultural Marketing and Prices. Principles and Applications. Living book series G. U. publication, Abuja, F.C.T Nigeria. Pp. 30-60

Taru, V.B., Jonathan, R., and Lawal, H. (2010). Structural analysis of Paddy markets in Southern part of Taraba State, Nigeria. Journal of Agriculture and Social Sciences, 6(4):110-112.

Vergriette, B. (2002). (ed) Contrats et concertation entre acteurs des filières vivirères. Paris InterRéseaux, Solagral, $87 \mathrm{p}$.

Vu Trong, B., and Casabianca, F. (2002). La construction d'un cahier des charges de production, comme outil d'organisation des producteurs et d'insertion dans la filière tomate. 